\title{
Evaluation of the Groundwater Quality of the Miocene Aquifer and its suitability for Domestic and Agriculture Purposes, West Nile Delta, Egypt
}

\author{
Ahmed ElMahmoudi ${ }^{1}$, Ahmed S. Shalaby ${ }^{1}$, Hatem Aboelkhair ${ }^{2}$ and Eslam Rashad ${ }^{* 2}$ \\ ${ }^{1}$ Geology Department, Faculty of Science, Mansoura University, El-Mansoura, Egypt. \\ ${ }^{2}$ Geology Department, Faculty of Science, Damietta University, Damietta, Egypt.
}

Received: 22 September 2020 /Accepted: 2 December 2020

*Corresponding author's E-mail: eslamrashad@du.edu.eg

\begin{abstract}
This study was conducted to evaluate factors regulating groundwater quality in an area with agriculture as main use. Thirty three groundwater samples have been collected from the area between El-Sadat and El-Khatatba city. The study area covers an area of approximately $634 \mathrm{~km} 2$. Rapid development in recent years has led to an increased demand for water, which is increasingly being fulfilled by groundwater abstraction. A detailed knowledge of the water quality can enhance understanding of the hydrochemical system, to achieve this; a hydrochemical investigation was carried out in the study area. Groundwater samples were chemically analyzed for major physicochemical parameters in order to understand the different geochemical processes affecting the groundwater quality. The analytical results show higher concentration of total dissolved solids (21\%), chloride (24\%), and total hardness (30\%), calcium (9\%) and sodium (36.4\%) which indicates signs of deterioration as compared with limits of WHO (2011) standards. On the other hand, 3\% groundwater sample is unsuitable for irrigation purposes according to Soluble Sodium Percent (SSP) and Kelley's Ratio (KR) represent $60 \%$ of samples are suitable based on irrigation quality parameters. The study revealed that application of fertilizer for agricultural contributing the higher concentration of ions in aquifer of Miocene.
\end{abstract}

Keywords: hydrochemical parameters

\section{Introduction}

Consumption of groundwater, nowadays, represents about one-third of the total freshwater in the world. Generally, shallow groundwater is easily accessible using conventional water well technologies. In contrast, deep groundwater is largely unexploited. Advanced technologies developed in the petroleum industry have been used to reach the deeper groundwater in order to conventional purposes.

Land area of Egypt is about one million $\mathrm{km}^{2}, 94 \%$ of which is desert. Currently, the population of the country is estimated as 104 million. Although, The Nile Delta covers only about 2\% of Egypt's area but hosts about $41 \%$ of the country's population and involves nearly $63 \%$ of its agricultural land. It is among the most densely populated agricultural areas in the world, with 1,360 inhabitants per $\mathrm{km}^{2}$. Egypt faces great challenges because of its limited 
water resources. Three dependent sources of water in Egypt: Nile water, groundwater, and drainage water. Rainfall is scarce and has a limited contribution to the water budget of the country. The Nile water is almost the only renewable source of water.

The Egyptian share from the Nile water, according to the international agreements, is limited to 55.5 billion $\mathrm{m}^{3}$ per year since 1959 . The per capita share from the renewable water is about $900 \mathrm{~m}^{3} /$ year. In $1992,4.5$ billion $\mathrm{m}^{3}$ of drainage water were reused, while 11.7 billion $\mathrm{m}^{3}$ of low quality drainage water were expelled to the Mediterranean Sea and northern lakes. Additional reuse of agriculture and industrial drainage water is not recommended because of its low quality and high contents of chemicals and pesticides. Unwise reuse of drainage water may cause serious environmental impacts.

Study area: The area of the study is a part of northwestern Nile Delta fringe; on both sides of Cairo-Alexandria desert road. It is bordered by Rosetta Branch in the east, and Eadi El Natrun, between longitudes $30^{\circ} 27^{\prime}$ and $30^{\circ} 55^{\prime} \mathrm{E}$ and latitudes $30^{\circ} 21^{\prime}$ and $30^{\circ} 08^{\prime} \mathrm{N}$, with total area about $634 \mathrm{~km}^{2}$ (Fig.1).

Climate: Generally, the study area is characterized by semiarid to arid climatic conditions, where it is hot in summer, and cold to moderate in winter. It is characterized in general by a short rainy season with low and infrequent rainfall, high annual temperature variations, high evaporation and high relative humidity. The maximum temperatures were recorded from May to October. While minimum ones were between December and March. The lowest value was recorded in January $\left(8.93^{\circ} \mathrm{C}\right)$, while the highest value of $36.86^{\circ} \mathrm{C}$ was recorded in July. The mean annual temperature averaged $29.42^{\circ} \mathrm{C}$. the rainfall distribution values occur during the cold season between Autumn and Spring precipitation the maximum value $(18.57 \mathrm{~mm})$ is in January, while the minimum one $(0.58 \mathrm{~mm})$ occurred in October. The mean annual rainfall averaged $5.5 \mathrm{~mm}$.

\section{GEOMORPHOLOGIC SETTING}

The western Nile Delta fringe is generally characterized by slightly undulating topography and higher land comparing with those of cultivated part of Nile Delta where the highest point is found in Qaret El Haddadein plateau where its ground elevation attains $+223 \mathrm{~m}$ above mean sea level and the lowest point is located at
Wadi El Natrun with approximately elevation of $23 \mathrm{~m}$ below mean sea level Embaby (2003). Generally, the geomorphologic studies of the area west of the Nile Delta were addressed by many authors such as Sandford and Arkell (1939), Said (1990), Shata and El Fayoumi (1967), Abu El-Izz (1971), El Shazly et al. (1975), and Embaby (2003). Most of those Authors classified the western fringe of the Nile Delta into six significant landforms. The area under study is distinguished by Shata and El-Fayoumy, (1967); Abdel Baki, (1983) and Gomaa, (1995) into the following three geomorphologic units: (1) The Old Alluvial Plains, (2) Wadi El-Natrun Structural Depression and (3) Gebel El Hadid Tableland. A thin blanket of dark brown gravel and conglomerate covers the surface. It is dissected by a number of old drainage channels.

Embaby (2003) suggested a new detailed geomorphologic map (Fig. 2) where the west Nile Delta can be classified into the following geomorphologic units: The high lands $2-$ The lowland 3 - The pediment and piedmont slops 4 The old alluvial plain 5 - The young alluvial plain 6 - The eolian sand and sand dunes and 7 - The drainage system.

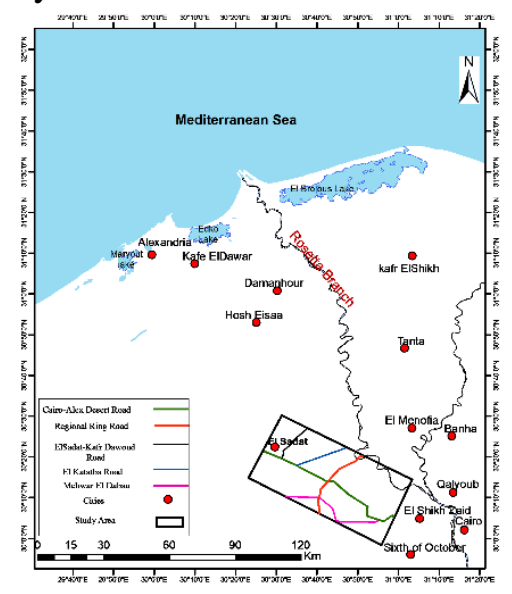

Fig.1 Location map of the study area

\section{GEOLOGIC SETTING:}

The geology of the west Nile Delta is discussed by several authors such as Sandford and Arkell (1939), Shata (1953, 1955, 1959 and 1967), El Fayoumy (1964), Shata et al. (1970 and 1978), Sanad (1973), El Ghazawi (1982), and Shedid (1989).The exposed rocks in the area (Fig. 3) belong to Cenozoic. The Oligocene outcrops are composed of sand, sandstone, gravel, and basalt. They are locally characterizing the southwest corner of the Nile Delta. The Oligocene basalt 
sheets are the only exposed volcanic rocks in the West Nile Delta area, particularly in the southeastern portion. Neogene sediments are generally dominating the southern and western parts at El Ralat, Wadi El-Natrun, and Wadi ElFarigh depressions as well as at El-Washika, Dahr El-Tashasha, and Gebel El-Hadid ridges. They are composed of sand and sandstone with clay and limestone intercalations. The Quaternary sediments are mainly clastic with essential sand facies and occasional gravel and clay intercalations. Sand sheets and sand dunes are detected toward the north.

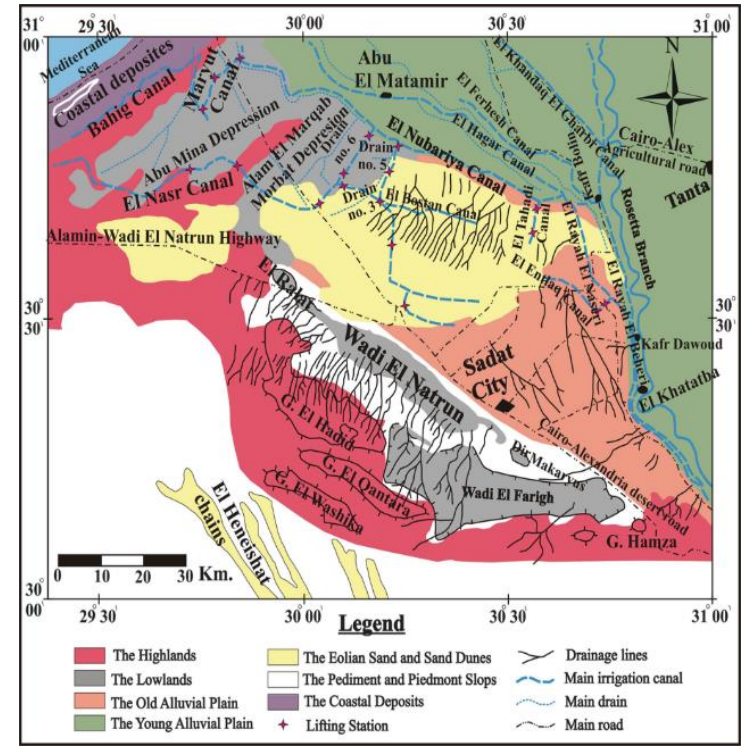

(Fig. 2) Detailed geomorphologic map characterized by landforms of the study area and its environs (after Negm, 2019).

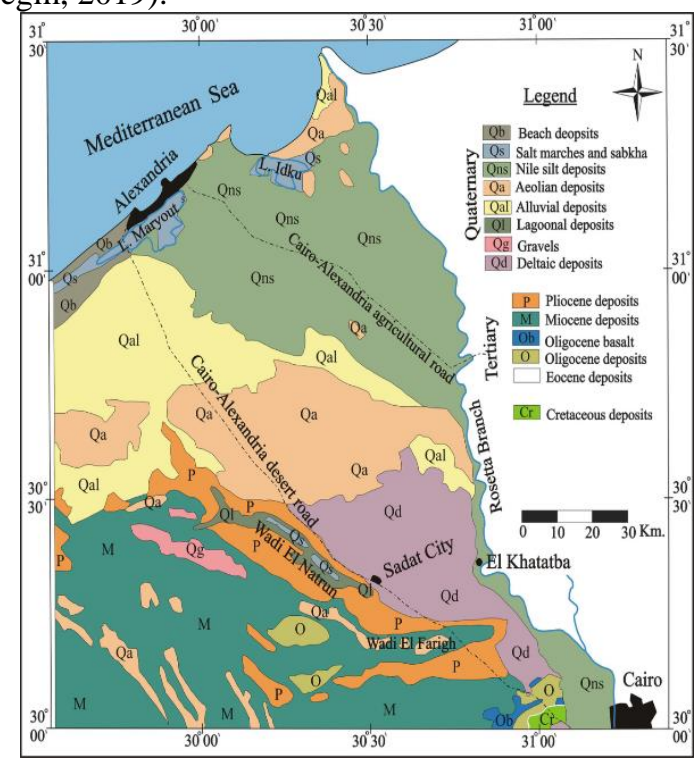

Fig. 3 Geological map of the area west of Nile Delta (after Negm, 2019).

\section{Material and Methods}

The current study was designed to investigate the conditions of groundwater contamination in the study areas. The hydro geochemistry study was undertaken by randomly collected 33 groundwater samples covering the study area during 2019.show table (1) Samples were drawn with a precleaned plastic polyethylene bottle. Prior to sampling, all the sampling containers were washed and rinsed thoroughly with the groundwater. Water quality parameters such as $\mathrm{pH}$, electrical conductivity (EC) and Total dissolved solids (TDS) were analyzed immediately. Other parameters were later analyzed in the laboratories. Total hardness $(\mathrm{TH})$ as $\mathrm{CaCO} 3$ and calcium $(\mathrm{Ca})$ were computed by equation $\mathrm{CaCO3}=\mathrm{Ca}^{++}(\mathrm{mg} / \mathrm{l}) * \mathbf{2 . 4 9 7}+\mathrm{Mg}^{++}$ $(\mathrm{mg} / \mathrm{l}) * 4.116$. Magnesium $(\mathrm{Mg})$ was determined by using atomic absorption spectrophotometer. (Ca) was determined titrimetrically. Chloride $(\mathrm{Cl})$ ) was determined titrimetrically by standard $\mathrm{AgNO}_{3}$ titration. The content of Sodium (Na) and Potassium (K) in groundwater was estimated flame photometrically. All parameters are expressed in milligrams per litre $(\mathrm{mg} / \mathrm{l})$ and milliequivalents per litre (meq/l), except $\mathrm{pH}$ (units) and electrical conductivity (EC). The electrical conductivity (EC) is expressed in micromohs $/ \mathrm{cm}(\mu \mathrm{S} / \mathrm{cm})$ at $25^{\circ} \mathrm{C}$.

\section{Results and Discussion}

Thirty three groundwater samples were drawn from the wells which included hand pumps, piped water supplies and mini water supply schemes as well as open wells These samples were analyzed for physicochemical parameters. The results of the physicochemical analysis are presented in tables1 and table- 2 show the critical parameters higher than the permissible limits given by WHO (2011).. pH: $\mathrm{pH}$ is one of the important factors of ground water. The $\mathrm{pH}$ values range from 6.21to 7.97 with an average of 7.05. The variations of $\mathrm{pH}$ values are mostly due to the chemical composition of the rocks constituting the aquifer and the distance from seawater. $94 \%$ of samples fall in permissible limit prescribed by WHO (2011) (7.5-8.5) (table $3)$. 
Table (1): Number of wells and depths for collected samples.

\begin{tabular}{c|c|c|c|c|c}
\hline $\begin{array}{c}\text { No. of } \\
\text { well }\end{array}$ & $\begin{array}{c}\text { Depth to } \\
\text { Water }\end{array}$ & W.L & $\begin{array}{c}\text { No. of } \\
\text { well }\end{array}$ & $\begin{array}{c}\text { Depth to } \\
\text { Water }\end{array}$ & W.L \\
\hline 1 & 97 & -34 & 18 & 120 & 0 \\
\hline 2 & 105 & -27 & 19 & 90 & -19 \\
\hline 3 & 95 & -24 & 20 & 80 & -23 \\
\hline 4 & 95 & -22 & 21 & 62 & -17 \\
\hline 5 & 100 & -23 & 22 & 75 & -37 \\
\hline 6 & 85 & -1 & 23 & 150 & -34 \\
\hline 7 & 100 & -24 & 24 & 60 & -31 \\
\hline 8 & 118 & -40 & 25 & 71 & -15 \\
\hline 9 & 125 & -40 & 26 & 70 & -13 \\
\hline 10 & 100 & -31 & 27 & 80 & -21 \\
\hline 11 & 80 & -9 & 28 & 73 & -12 \\
\hline 12 & 70 & -8 & 29 & 110 & -44 \\
\hline 13 & 70 & -10 & 30 & 100 & -23 \\
\hline 14 & 70 & 0 & 31 & 95 & -44 \\
\hline 15 & 108 & -31 & 32 & 45 & 0 \\
\hline 16 & 90 & -10 & 33 & 36 & 6 \\
\hline 17 & 130 & -20 & & & \\
\hline
\end{tabular}

Total dissolved solids (TDS): The total dissolved solids (TDS) are the concentrations of all dissolved minerals in water indicate the general nature of salinity of water. The total dissolved solids in all the study area varies from 279 to 3810 $\mathrm{mg} / \mathrm{l}$ with an average of $(1060 \mathrm{mg} / \mathrm{l})$

(table 2). The higher value of total dissolved solids is attributed to application of agricultural fertilizer contributing the higher concentration of ions into the groundwater. $21 \%$ of samples were exceeding maximum permissible limit (table 3 ) prescribed by the WHO (2011).500-1000 mg/l Calcium (Ca): Calcium is naturally present in water. Calcium is a determinant of water hardness, because it can be found in water as $\mathrm{Ca}$ ions. Calcium content in the groundwater varies from 16.09 to $382.8 \mathrm{mg} / \mathrm{l}$ With an average of $(90.56$ $\mathrm{mg} / \mathrm{l}$ ) (table 1). Only 9\% of samples were Exceeding themaximum permissible limit (table 2) prescribed by the WHO (2011) < 75 $\mathrm{mg} / \mathrm{l}$.Magnesium (Mg): Magnesium is washed from rocks and subsequently ends up in water. Magnesium has many different purposes and consequently may end up in water in many different ways. Chemical industries add magnesium to plastics and other materials as a fire protection measure or as filler. It also ends up in the environment from fertilizer application and from cattle feed. The values of magnesium range from 12.66 to $40.23 \mathrm{mg} / \mathrm{l}$ with an average of $(30.56 \mathrm{mg} / \mathrm{l})$

(table 2). All samples were within the permissible limit (table 3).

Total hardness (TH): Total Hardness is considered as a major character of drinking water. Hardness is defined as the concentrations of calcium and magnesium ions. Calcium $(\mathrm{Ca})$ and magnesium $(\mathrm{Mg})$ are dissolved from most soils and rocks. A total hardness value varies from 95 to $1099 \mathrm{mg} / \mathrm{l}$ with an average of $(351.9 \mathrm{mg} / \mathrm{l})$ (table 1) which may be due to presence of Calcium (Ca) and magnesium $(\mathrm{Mg})$. The study concluded that $30 \%$ of the samples were exceeding maximum permissible limit (table 2) prescribed by the WHO (2011) 250-500 mg/l.

Chloride (Cl): Chloride originates from sodium chloride dissolved in water from rocks and soil. It is good indicator of groundwater quality and its concentration in groundwater will increase if it mixed with sewage or sea water. The chloride content in the study area has shown variation from 50 to $1469 \mathrm{mg} / \mathrm{l}$ with an average of $(379 \mathrm{mg} / \mathrm{l})$ (table 1). About $24 \%$ of samples were crosses the maximum permissible limit (table 2) prescribed by WHO (2011).250-300 mg/l

Bicarbonate alkalinity (HCO3): Alkalinity is the measure of the capacity of the water to neutralize a strong acid. The Alkalinity in the water is generally imparted by the salts of carbonates, silicates, etc. together with the hydroxyl ions in Free State Trivedy, \& Goel (1984). The bicarbonate alkalinity varies from 92 to $414 \mathrm{mg} / \mathrm{l}$ (table 1).

Table (2): Composition of the groundwater samples from the drilled wells at the study area.

\begin{tabular}{|l|l|l|l|l|l|}
\hline Range & $\begin{array}{l}\text { Mini } \\
\text { mum }\end{array}$ & $\begin{array}{l}\text { Maxi } \\
\text { mum }\end{array}$ & $\begin{array}{l}\text { Stan } \\
\text { dard } \\
\text { Devi } \\
\text { ation }\end{array}$ & $\begin{array}{l}\text { Mea } \\
\text { n }\end{array}$ & $\begin{array}{l}\text { Medi } \\
\text { an }\end{array}$ \\
\hline $\mathrm{pH}$ values & 6.21 & 7.97 & 0.38 & 7.05 & 7.05 \\
\hline $\begin{array}{l}\text { E.C. } \\
(\mu \mathrm{mohs} / \mathrm{cm})\end{array}$ & 419 & 5730 & 1231.21 & 1531.4 & 1167 \\
\hline $\begin{array}{l}\text { T.D.S. } \\
(\mathrm{ppm})\end{array}$ & 279 & 3810 & 840.79 & 1060.12 & 787 \\
\hline $\mathrm{K}^{+}(\mathrm{ppm})$ & 3.44 & 55.03 & 8.99 & 12.56 & 10.5 \\
\hline $\mathrm{Na}^{+}(\mathrm{ppm})$ & 64.08 & 777.08 & 165.07 & 215.16 & 140.33 \\
\hline $\mathrm{Ca}^{++}(\mathrm{ppm})$ & 16.09 & 382.8 & 85.57 & 90.56 & 48.25 \\
\hline $\mathrm{Mg}^{++}(\mathrm{ppm})$ & 12.66 & 40.23 & 7.25 & 30.56 & 32.72 \\
\hline $\mathrm{Cl}^{-}(\mathrm{ppm})$ & 50.67 & 1469 & 363.74 & 379.17 & 235.7 \\
\hline $\begin{array}{l}\mathrm{HCO}_{3}{ }^{-} \\
(\mathrm{ppm})\end{array}$ & 92.72 & 414.8 & 68.28 & 190.3 & 195.2 \\
\hline $\mathrm{SO}_{4}^{--}(\mathrm{ppm})$ & 10.93 & 883 & 231.6 & 206.4 & 109.94 \\
\hline $\mathrm{TH}^{-(\mathrm{ppm})}$ & 95.04 & 1099.5 & 230.05 & 351.9 & 268.67 \\
\hline
\end{tabular}


Table (3): Guidelines for the drinking water quality standards after U.S.EPA (1992) and WHO (2011).

\begin{tabular}{|c|c|c|c|c|c|c|c|}
\hline $\begin{array}{l}\text { Evaluation } \\
\text { indicators } \\
\text { classes }\end{array}$ & Symbol & \multicolumn{2}{|l|}{$\mathrm{pH}$} & \multicolumn{2}{|l|}{ T.D.S } & \multicolumn{2}{|l|}{ Hardness } \\
\hline Excellent & A & \multicolumn{2}{|l|}{$6.5-8.5$} & \multicolumn{2}{|l|}{$<500$} & \multicolumn{2}{|l|}{$<250$} \\
\hline Permissible & B & \multicolumn{2}{|l|}{$\sim$} & \multicolumn{2}{|l|}{$500-1000$} & \multicolumn{2}{|l|}{$250-500$} \\
\hline Excessive & $\mathrm{C}$ & \multicolumn{2}{|l|}{$\sim$} & \multicolumn{2}{|l|}{$1000-1500$} & \multicolumn{2}{|l|}{$\sim$} \\
\hline Unsuitable & $\mathrm{D}$ & \multicolumn{2}{|c|}{$<6.5 \&>8.5$} & \multicolumn{2}{|c|}{$>1500$} & \multicolumn{2}{|l|}{$>500$} \\
\hline \multirow{2}{*}{$\begin{array}{l}\text { Evaluation } \\
\text { indicators } \\
\text { classes }\end{array}$} & \multirow[t]{2}{*}{ Symbol } & \multicolumn{6}{|c|}{ Inorganic pollutant (major constituents) in mg/l } \\
\hline & & Sodium & Magnesium & \begin{tabular}{l|l} 
Calcium \\
\end{tabular} & Potasium & Chloride & Sulphate \\
\hline Excellent & $\mathrm{A}$ & $<150$ & $<50$ & $<75$ & 10 & $<250$ & $<250$ \\
\hline Permissible & $\mathrm{B}$ & $150-200$ & $\sim$ & $\sim$ & & $250-300$ & $250-300$ \\
\hline Excessive & $\mathrm{C}$ & $\sim$ & $50-150$ & $75-200$ & & $300-500$ & $300-500$ \\
\hline Unsuitable & $\mathrm{D}$ & $>200$ & $>150$ & $>200$ & 10 & $>500$ & $>500$ \\
\hline
\end{tabular}

Sodium (Na): Not only seas, but also rivers and lakes contain significant amounts of sodium. Concentrations however are much lower, depending on geological conditions and waste water contamination sodium compounds serve many different industrial purposes, and may also end up in water from industries. The Sodium content in study area exhibits variation from 64 to $777 \mathrm{mg} / \mathrm{l}$ (table 1) with an average of $(215.16$ $\mathrm{mg} / \mathrm{l})$. About $36.4 \%$ of samples were crosses the maximum permissible limit (table 2) prescribed by WHO (2011)150-200 mg/l.

Potassium (K): Potassium is an essential element for humans, plants and animals, and derived in food chain mainly from vegetation and soil. The main sources of potassium in groundwater include rain water, weathering of potash silicate minerals, use of potash fertilizers and use of surface water for irrigation. The European Economic Community (EEC; 1980) has prescribed the guideline level of potassium at $10 \mathrm{mg} / \mathrm{l}$ in drinking water. As per European Economic Community (EEC 1980) criteria about $60.6 \%$ of samples exceeding maximum permissible limit $10 \mathrm{mg} / \mathrm{l}$.

In conclusion,investigation the groundwater samples from different part of the study area revealed that there is a marked variation in groundwater quality. The analytical results show higher concentration of total dissolved solids $(21 \%)$, chloride $(24 \%)$, and total hardness $(30 \%)$, calcium (9\%) and sodium (36.4\%) than the standard figures given by WHO (2011) which indicates signs of deterioration.

\section{Suitability of groundwater for irrigation:}

Quality of water is very important with the increasing water demand on industries and agriculture and increasing in standard of living. Groundwater considers the main source of irrigation in the study area. The acceptable amount of water is very necessary for suitable growth of plants but the quality of water used for irrigation purpose should also be well within the permissible limit otherwise it could harmfully affect the plant growth.

The water used for irrigation is an important factor in productivity of crops, . The quality of irrigation water depends primarily on the presence and concentrations of dissolved salts. Sodium Absorption Ratio (SAR) and Residual Sodium Carbonate (RSC) are the most important quality criteria, which influence the water quality and its suitability for irrigation.

Sodium Absorption Ratio (SAR): Sodium adsorption ratio (SAR) is used as a measure of sodium replacing adsorbed calcium and magnesium. This ratio affects the physical properties of the soil, since the use of water having high SAR leads to a breakdown of its structure. Sodium is adsorbed and become attached to soil particles. The soil becomes hard and compacted when dry and impervious to water penetration. Irrigation water having SAR values from 1 to 10 is safe for soil structure. High sodium ion concentration in water causes low permeability of soil and hence infiltration of water becomes difficult. The presence of calcium and magnesium in soil allows easy cultivation and makes soil more permeable. The increase of sodium in soil causes replacing of calcium and magnesium and soil becomes hard and compact leading to reduced infiltration and poor internal drainage (Karanth 1987). The SAR values are calculated using the following equation (Richards 1954):

$\mathrm{SAR}=\mathrm{Na}^{+} /\left(\mathrm{Ca}^{+2}+\mathrm{Mg}^{+2} / 2\right)^{.5}$

Where the concentrations are expressed in meq/L. $\mathrm{mg} / \mathrm{l}$ The potential for a sodium hazard increases in waters with higher sodium adsorption ration (SAR) values. The sodium adsorption ration 
(SAR) content determined in the in study area varies from 2 to $20 \mathrm{meq} / \mathrm{L}$ with low and medium sodium hazard that safe to irrigation uses. $84.85 \%$ of Sodium adsorption ratios for the groundwater samples in the study area are less than 10 indicating excellent quality for irrigation. Samples fall in excellent (S1) category while $15.15 \%$ Sodium adsorption ratios fall within range 10-18 indicating good quality.

Table (4): Classification of groundwater on the basis of SAR, KR, SSP and RSC

\begin{tabular}{|c|c|c|c|}
\hline Parameter & Range & Water Class & $\begin{array}{c}\text { Samples } \\
\text { percentage }\end{array}$ \\
\hline \multirow[t]{4}{*}{$\begin{array}{l}\text { SAR } \\
\text { Fipps, } 1996\end{array}$} & $<10$ & $\begin{array}{l}\text { Low } \\
\text { Hazard(S1) } \\
\text { Excellent }\end{array}$ & $84.85 \%$ \\
\hline & $10-18$ & $\begin{array}{l}\text { Medium } \\
\text { Hazard (S2) } \\
\text { Good }\end{array}$ & $15.15 \%$ \\
\hline & $18-26$ & $\begin{array}{l}\text { High Hazard } \\
\text { (S3) } \\
\text { Permissible }\end{array}$ & - \\
\hline & $>26$ & $\begin{array}{ll}\text { Very high } \\
\text { Hazard (S4) } \\
\text { unsuitable }\end{array}$ & - \\
\hline \multirow{3}{*}{$\begin{array}{l}\text { KR } \\
\text { Kelley, } 1963\end{array}$} & $<1$ & Suitable & $33.3 \%$ \\
\hline & $1-2$ & $\begin{array}{l}\text { Marginally } \\
\text { suitable }\end{array}$ & $60.6 \%$ \\
\hline & $>2$ & Unsuitable & $6.1 \%$ \\
\hline \multirow[b]{2}{*}{$\begin{array}{l}\text { Soluble } \\
\text { sodium } \\
\text { percent } \\
\text { (U.S. } \\
\text { Salinity } \\
\text { Laboratory } \\
\text { Staff, 1954) }\end{array}$} & $<75 \%$ & Good & $97 \%$ \\
\hline & $>75 \%$ & Bad & $3 \%$ \\
\hline \multirow{3}{*}{$\begin{array}{l}\text { RSC } \\
\text { (Eaton, } \\
1950)\end{array}$} & $<1.25$ & Suitable & $94 \%$ \\
\hline & $\begin{array}{ll}1.25 & - \\
2.50 & \\
\end{array}$ & $\begin{array}{l}\text { Medium } \\
\text { suitable }\end{array}$ & $3 \%$ \\
\hline & $>2.5$ & Unsuitable & $3 \%$ \\
\hline
\end{tabular}

Kelly's ratio (KR): Kelly's ratio (KR) was also estimated to evaluate the groundwater quality for irrigation purposes (Kelley 1963). It is defined as: $\mathbf{K R}=\mathbf{C a} /(\mathbf{C a}+\mathbf{M g})$

Where all the concentrations are in meq/L. KR > 2 indicates an excess level of sodium in waters and not suitable for irrigation. $33.33 \%$ of the samples shown in Table 5belong to suitable to marginally suitable category and $60.6 \%$ of the samples belong to marginally suitable to unsuitable category; while the rest of the samples belong to the unsuitable category.

SSP: The Soluble Sodium Percent (SSP): The soluble sodium percent (SSP) is used to evaluate sodium hazard. The SSP is defined as the ratio of sodium in epm to the total cations in epm multiplied by 100 . The U.S. Salinity Laboratory Staff (1954) recorded that water is excellent and can be used for irrigation without any troubles; if it has less than $75 \%$ SSP and salinity less than $1000 \mathrm{mg} / \mathrm{l}$. Soluble sodium percentage (SSP) is an important parameter to assess the sodium hazard towards irrigation. It is defined by Todd (1959) as shown below:

$\mathrm{SSP}=(\mathrm{Na}+* 100) /\left(\mathrm{Mg}^{+2}+\mathrm{Ca}^{+2}+\mathrm{K}^{+}\right)$in epm.

According to U.S. Salinity Laboratory Staff (1954), irrigation canals and groundwater samples has SSP less than $75 \%$ suggesting excellent water which can be used for irrigation without any troubles.

According to U.S. Salinity Laboratory Staff (1954) the first class has SSP less than $75 \%$ includes $97 \%$ of samples while 3\% only of samples exceed $75 \%$ (Table4).

Residual sodium carbonate (RSC): RSC is also an important parameter for assessing the groundwater suitability for irrigation; it is defined as (Eaton 1950):

$\mathrm{RSC}=\left(3^{--}+\mathrm{HCO}_{3}^{-}\right)-\left(\mathrm{Ca}^{++}+\mathrm{Mg}^{++}\right)$in epm

RSC examines the quality of water especially for irrigation purposes (Eaton, 1950). RSC $<1.25$ indicates suitability of water for irrigation while $1.25-2.5$ is in doubtful category and greater than 2.5 are not useful for irrigation (Lloyd and Heathcote 1985). Therefore, the irrigation water will be generally suitable if the RSC is negative or less than 1.25, and is unsuitable if its RSC is more than 2.5 (Table 4). 96\% of groundwater samples appear suitable while $3 \%$ of samples fall within unsuitable category and 3\% of samples represent medium suitable.

\section{Conclusion}

The analytical results show higher concentrations for total dissolved solids (21\%), chloride (24\%), total hardness (30\%), calcium (9\%) and sodium (36.4\%) indicating signs of deterioration as per WHO (2011) standards. The groundwater of the Miocene aquifer exhibits conductivities from 419 to $5730 \mu \mathrm{mohs} / \mathrm{cm}$. Thus proper drainage systems is required where electrical conductivity (EC) is more than $1500 \mu \mathrm{mohs} / \mathrm{cm}$. A few wells of the study area record extraordinary values of conductivity and chloride due to the application of fertilizer for agricultural thus exhibiting the higher concentration of ions contribute to groundwater degradation in varying degrees. On the other hand, $3 \%$ of the groundwater sample is unsuitable for irrigation purposes according to Soluble Sodium Percent (SSP), Kelley's Ratio (KR) represents 
$60 \%$ of samples are suitable, Residual sodium carbonate (RSC) represents $94 \%$ of samples are suitabletoo, while Sodium Absorption Ratio (SAR) show $15.15 \%$ of the samples fall in unsuitable category .It is assumed that application of fertilizer for agricultural causes the higher concentration of ions in aquifer of Miocene.

Recommendations: This study emphasizes the need for regular groundwater quality monitoring to assess pollution activity from time to time for taking appropriate management measures in time to mitigate the intensity of pollution activity. The remedial measures include: i) Rain water harvesting should be encouraged. Excess rain water stored should be directed to recharging wells. ii) Encourage the framers to use biofertilizers and biopesticides to avoid the soil, surface water and groundwater contamination.

\section{Reference:}

Abu El-Izz, M.S., 1971. Landforms of Egypt. The American Univ. Press, Cairo, pp. 128-154.

ECAFA and UNESCO (1963): The development of groundwater resources with special reference to deltaic areas. United Nations, New York1,155 p.

WHO (2011). World Health (WHO) Organization Fourth ed "Guideline for drinking water quality". EEC (European Economic Communitites) Richtlinic des Rates Vem., 15.71980 liber die qualitat Von Wasser furden menschlichen Gebrauch. Amtslelatt der Europaischen gemeinschaft vom. 30-8 No. L 229, 11-29 (1980).

El Fayoumy, I. F. (1964). Geology of ground water supplies in Wadi El Natrun area (Doctoral dissertation, Verlag nicht ermittelbar).

El Ghazawi, M. M. (1982). Geological studies of the Quaternary-Neogene aquifers in the area northwest Nile Delta. M.Sc. Thesis, Faculty of Science, AlAzhar University, Cairo, Egypt, $170 \mathrm{p}$

El Shazly, E.M., Abdel-Hady, M., El Ghawaby, H., El Kassas, k., Khawasik, S.M., El Shazly, M.M., Sanad, S., 1975. Geologic Interpretation of Landsat Satellite Image for West Nile Delta Area, Egypt. The Remote Sensing Center, Academy of Scientific Research and Technology, Cairo, 38p.

Embaby, A. A. A. (2003). Environmental evaluation for geomorphological situation in relation to the water and soil resources of the region north of the Sadat City, west Nile Delta, Egypt. Unpublished Ph. D. Thesis, Fac Sci Mansoura Univ. Egypt, 323, 60.
Fipps, G. (1996): Irrigation water quality standards and salinity management. Taxas Agricultural Extension Service. B- 1667, 19p.

Kelly, W. P. (1940). Permissible composition and concentration of irrigation waters. Proceedings of ASCE, 66,607.

Trivedy, R. K., \& Goel, P. K. (1984). Chemical and biological methods for water pollution studies. Environmental publications Karad. India PP 215.

Todd, D. K. (1959). Groundwater hydrology (p. 535).New York: Wiley.

Said, R. 1990. Geomorphology. In: The Geology of Egypt (Edited by Said, R.) pp9-26. A. A. Balkema, Rotterdam.

Salem, R. 1976. Evolution of Eocene-Miocene sedimentation patterns in parts of northern Egypt. American Association Petroleum Geologists Bulletin 60. 34-64.

Sandford, K. S., \& Arkell, W. J. (1939). Paleolithic Man and the Nile Valley in Lower Egypt, with some notes upon a part of the Red Sea littoral. Univ. Chicago Orient. Inst. Publ., 46, 105.

Sanad, S. (1973). Geology of the area between Wadi El-Natrun and the Moghra depression. Ph. D. Thesis, Assuit University.

Shata, A.A., 1953. New light on the structural development of the Western Desert of Egypt. Bull. Inst. Desert d'Egypte T. III (1), 101-106.

Shata, A.A., 1955. An introductory note on the geology of northern portion of the Western Desert of Egypt. Bull. Inst. Desert d' Egypte T. V (1), 96-106.

Shata, A.A., 1959. Geological problems related to the groundwater supply of some desert areas of Egypt. Bull. Soc. Geogr. d' Egypte T. 32, 247-262.

Shata, A., \& El Fayoumi, I. F. (1967). Geomorphological and morphopedological aspects of the region west of the Nile Delta with special reference to Wadi El Natrun area. Desert Inst Bull, 17, 1-28.

Shata, A.A., El Fayoumi, I.F., Tamer, M., 1970. Geomorphology, Geology, Hydrology and Soils of Wadi El Natrun-Maryot Agriculture Project. Pubi. Institute Desert.

Shata, A.A., El Shazly, M.M., Attia, S.H., AboulFetouh, M., 1978. The geology of the quaternary deposits and their natural relation to soil formations in the fringes west of the Nile Delta, Egypt. Desert Inst. Bull., ARE 28 (1), 43-77.

Shedid, A. G. (1989). Geological and hydrogeological studies of El Sadat area and its vicinities (Doctoral dissertation, M.Sc. Thesis Faculty of Science, El Menoufia University, Shibin El Kom, p 157).

United State Salinity Laboratory Staff "USSL" (1954): Diagnosis and improvement of saline and alkali soil. United State Department of Agriculture Handbook No. (60), U.S. Printing Office, 
Washington D.C., pp: 1-66.

United State Environmental Protection Agency
"U.S.EPA" (1992): Groundwater Handbook, 2nd Ed. Government Inst., Inc. USA, Vol. 2, 141p.

الملخص العربي

\title{
عنوان البحث: تقييم جودة المياه الجوفية للخزان الميوسيني ومدى ملائمتها للأغراض المنزلية و والزراعية، غرب دلتا النيل، مصر.
}

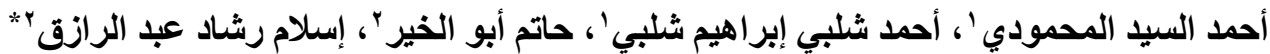

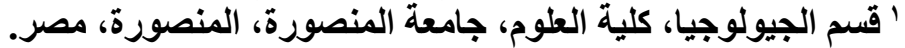

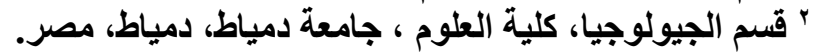

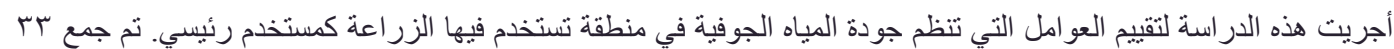

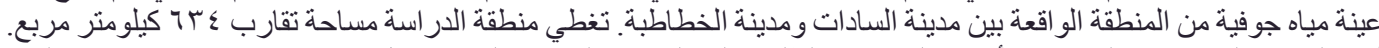

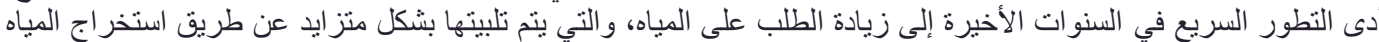

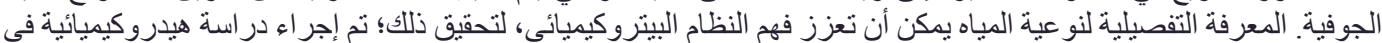

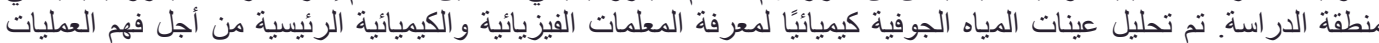

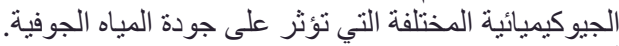

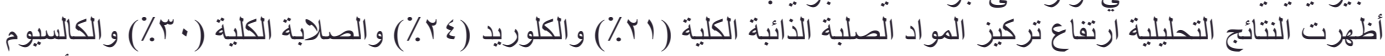

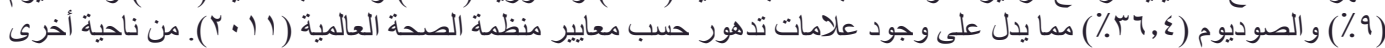

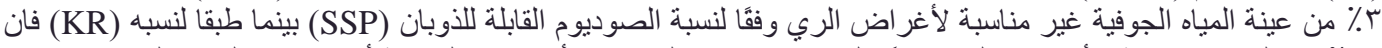

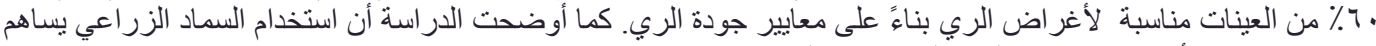
في زيادة تركيز الأيونات في طبقة المياه الجوفية في الميوسين. 